association between psychosis and genius, otherwise they would surely not have dismissed the possibility so cavalierly, i.e. without providing some negative evidence in support of their assertion of mythicality. Can I therefore briefly mention a few of the studies which refute the 'mythicality' of an association that is strongly held in the popular imagination?

Lange-Eichbaum' found that, of a group he considered the outstanding geniuses in human history, almost a half had at some time suffered from psychosis. Karlsson ${ }^{2}$ showed, in a sample of 132 world-famous creative persons, that their lifetime risk of psychosis was consistently of the order of 25-40 per cent (philosophers having the highest rate). Various personality (MMPI) ${ }^{3,4}$ and projective (Rorschach) test studies have purported to demonstrate a 'schizophrenic' personality structure in persons of creative genius, such as renowned American architects, painters and writers. The loosening of associations in such individuals leads to heuristic 'lateral' (De Bono) or 'allusive' thinking, reminiscent of the tangentiality of schizophrenic thought disorder. These people put together ideas or imagery most of us would not; they prefer complexity and novelty. To give but a few examples: Sir Isaac Newton and Michael Faraday were psychotic by middle age, Oliver Cromwell and Abraham Lincoln had their spells of madness, as had William Pitt the Elder and Younger. Goethe (whose sister was also psychotic), Kant, Nietzsche, Schopenhauer, Mendelssohn, Schubert, Wolf, Schumann, Wagner, Guy de Maupassant and probably Edgar Allan Poe and Victor Hugo all had psychotic periods. Siegfried Sassoon, Florence Nightingale and Nijinsky were all mentally unstable. The psychoanalysts Tausk and Reich had tragic ends, as did Frank Fish and Richard Asher.

Insanity might also be linked to genius in corollary fashion, i.e. close blood relatives might show an elevated risk of psychosis. Thus Karlsson ${ }^{6}$ showed that the likelihood of being listed in the Icelandic Who's Who was almost twice as high for close relatives of psychotic patients (especially manic-depressives) as for the population at large. Juda' surveyed a large group of gifted Germans with similar results Myerson and Boyle ${ }^{8}$ reported an elevated psychosis rate in

\section{Cambridge Group Work}

Cambridge Group Work was formed in 1975. Its object is to provide experience in groups for training, personal growth and therapy, as well as theoretical training and opportunities for research. Last season a total of 67 persons took part in one or more of the Cambridge Group Work activities. In addition to the annual courses, supervision seminars were introduced for those who conduct groups as part of their professional work. Conductors were provided for sensitivity groups and staff supervision in various institutions. Group-analytic psychotherapy is also provided.

The programme for 1983/84 may be obtained from Mrs Julie Aston, 4 Manor Walk, Fulbourn, Cambridge CB1 SBN. eminent American families. The fathers of Shelley, Chaplin and Hans Christian Anderson, the sisters of Charles Lamb and Tennessee Williams, the brothers of the Brontë sisters and of Victor Hugo (whose daughter was also affected) were all known schizophrenics. The mother of Camus, the sons of Einstein and Coleridge, Wordsworth's daughter and sister may, too, be mentioned in this context.

The evidence for an association is persuasive rather than conclusive. The definitive studies have yet to be done, but there is surely a prima facie case which merits more than a blanket dismissal.

(It is interesting in this context that your correspondent (Bulletin, July 1983, 129) referred to Arthur Koestler as being especially perspicacious in terms of creativity, in the light of the recent suicide of him and his wife.)

Botleys Park Hospital

H. G. KINNELL

Chertsey, Surrey

REFERENCES

'LANGe-Eichbaum, W. (1928) Genie, Irrsinn and Ruhm. Munchen: Reinhardt.

${ }^{2}$ KARLSSON, L. (1974) Schizophrenia and creativity. In Inheritance of Schizophrenia (p. 76). Acta Psychiatrica Scandinavica, Supplementum 247. Copenhagen: Munksgaard.

'MACKINNON, D. W. (1962) The nature and nurture of creative talent. American Psychologist, 17, 484-95.

'BARron, F. (1963) Creativity and Psychological Health. Princeton: Van Nostrand.

'DUDEK, S. Z. (1970) The artist as a person: Generalization based on Rorschach records of writers and painters. Journal of Nervous and Mental Disease, 150, 232-41.

'KarLsson, L. (1974) Possible association of schizophrenia with giftedness. In Inheritance of Schizophrenia (p. 81). Acta Psychiatrica Scandinavica, Supplementum 247. Copenhagen: Munksgaard.

'JUDA, A. (1949) The relationship between highest mental capacity and psychic abnormalities. American Journal of Psychiatry. 106, 296-309.

'Myerson, A. \& Boyle, R. D. (1941) The incidence of manic depressive psychosis in certain socially important families. American Journal of Psychiatry, 98, 11-21.

\section{Help in research and writing research papers}

Junior authors of papers submitted to the Journal but rejected may now turn to the Research Committee for assistance. The Secretary of the Committee (Dr Sheila Mann at the College address) is prepared to find an adviser who will give the author some guidance on how to write research papers.

In 1980 the Research Committee produced a free leaflet entitled 'Hints on Research'. This has been circulated to all tutors and is available to any individual who requests it from Miss Jane Boyce at the College address. The leaflet makes suggestions on how to find a subject for research, how to plan it in some detail, and where to seek for funds. 